\title{
Hemodialysis and Oral Health
}

\section{ABSTRACT}

Aims of study: The purposes of this study were to evaluate the oral health, the educational level and decay frequency in hemodialysis patients. Materials and Methods: This study was conducted on 100 patients, 43 of them were controlled patients admitted to the general dental unit in Al-Salam Hospital, while the remaining 57 patients underwent hemodialysis in the Dialysis Unit in Ibn-Sina Hospital in Mosul. Special consent form for each patient was obtained along with a noninvasive oral examination. Results: By using SPSS, significant pvalue was detected between education level \& disease, the visit to dentist \& disease. ANOVA test was done for study groups \& gingival index, plaque index showed significant relation. For decayed teeth, significant pvalue was observed. Conclusion: Present study results confirm the hypothesis that periodontal disease prevalence exists in hemodialysis patients, so regular dental visits are needed to ensure optimal oral health in dialysis patients. Education of hemodialysis patients for their oral health and bilateral motivation between medical staff and dentists is mandatory.

\section{الخلاصة:}

الهلف من الاراسة : لنقيبيم صحة الفم واللثة و الأسنان في المرضى المصابين

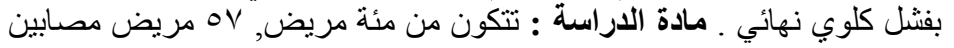

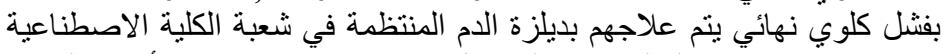

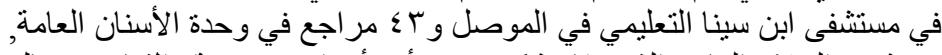

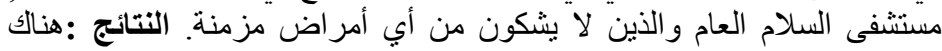

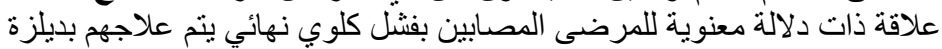

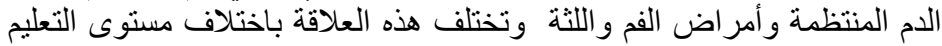
واختلاف عدد الزيارات لعيادة طب الأسنان لهؤلاء المرضى. الاستتنتاج: أظهرت

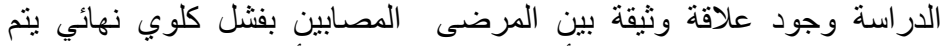

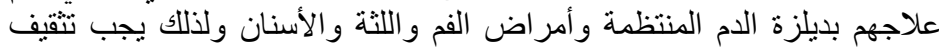

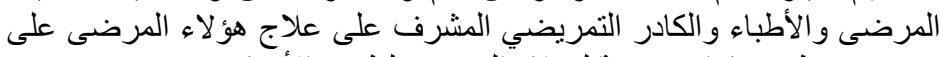
ضرورة تنظيم زيار ات دورية لهؤ لاء المرضى لطبيب الأسنان.

Key Words: Hemodialysis, oral health, education level.

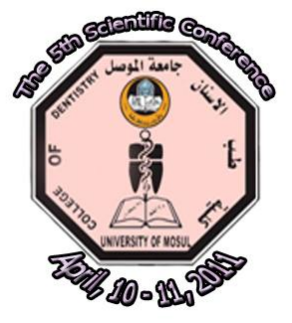

Rawaa Y. Kh. Al-Rawee (B.D.S, M.Sc., MOMSRCPS Glasgow) ${ }^{1}$; Raed Y. Kh. Al-Rawee (MBCHB, FICMS) 2

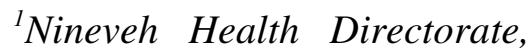
Ministry of Health; ${ }^{2}$ Nephrology Unit in Ibn-Sina Teaching Hospital, Nineveh, Ministry of Health. 


\section{INTRODUCTION}

hronic Kidney Disease (CKD) is defined as Kidney damage or glomerular filtration rate (GFR) less than $60 \mathrm{ml} / \mathrm{min} / 1.7 \mathrm{~m}^{2}$ for three months or more, irrespective of the cause ${ }^{(1)}$. The Kidney Disease Outcomes Quality Initiative (K/DOQI) has suggested staging CKD from stage 1 (mildest) to stage 5 (most sever) based on the level of the estimated glomerular filtration rate (GRF) normalized to body surface area, ESRD is stage 5 when the GFR is less than $15 \mathrm{ml} / \mathrm{min} / 1.7 \mathrm{~m}^{2}$, when renal replacement therapy in the form of dialysis or transplantation has to be considered to sustain life ${ }^{(2)}$.

There are two types of dialysis: peritoneal dialysis (PD) and hemodialysis (HD). In both types the patient's blood is separate from the dialysis fluid by a membrane (the patient own peritoneal membrane (PD), or a semi permeable synthetic membrane (HD) that allows water and toxins, but not blood cells, to pass out from the blood ${ }^{(3)}$. Even though renal transplantation and peritoneal dialysis subsequently can be used to treat patients successfully, hemodialysis is the default therapy for all patients with ESRD ${ }^{(4,5)}$. The true incidence and prevalence of CKD within a community is difficult to ascertain, as most people who have early-to-moderate Chronic Renal Failure are asymptomatic ${ }^{(6)}$. Diabetes Mellitus is the most common cause of CKD ${ }^{(7)}$.

Oral health is an integral and critical part of general health. CKD can affect oral tissues and lead to gingival enlargement, xerostomia, alterations in salivary composition ${ }^{(8)}$ and flow rate (9), adverse effects related to drug therapy, mucosal lesions, oral malignancies, oral infections, dental anomalies and bone lesions ${ }^{(3)}$.

There have been many studies evaluating the oral hyiegen and dental health status of HD patients. The mostly observed oral findings are xerostomia and parotitis ${ }^{(8,10,11)}$. An accelerated rate of calculus formation has also been reported in these patients, which was attributed to elevated salivary urea levels ${ }^{(8,12,13)}$. On the other hand, this was reported to contribute to remineralization of decayed dental enamel, which leads to lower caries levels in such patient $(9,14,15,16,17,18)$. Several studies ${ }^{(19,20)}$ evaluating plaque accumulation in CKD patients attributed higher plaque indices (PIs) in the oral neglect of these patients. Detecting oral problems in dialysis patients is of utmost importance for preventing potential infections ${ }^{(11,21)}$, because recent studies of the healthy population show that oral infections are associated with an increased risk of systemic complications ${ }^{(22,23)}$. Life with ESRD is miserable, food and fluid restrictions are mandatory for such patients due to hyperkalemia, high blood pressure and fluid retention ${ }^{(24,25)}$.

Aims of Study: The purposes of this study were to:

1. Evaluate the oral health \& oral complications that occur in hemodialysis patients.

2. Evaluate the relation between educational levels of our patients with their oral health maintenance.

3. Determine the relevant treatment needs according to their health status.

\section{MATERIALS AND METHODS}

This study was conducted on 100 patients aged between (18-70 years old), forty three of these were systematically healthy patients attended to the general dental unit in Al-Salam Teaching Hospital seeking dental treatment, the rest of the cases (57 patients) had CKD; who underwent hemodialysis at the Dialysis Unit in Ibn-Sina Teaching Hospital in Mosul which is the only center in Nineveh Governorate in Iraq. A questionnaire consent form and a noninvasive oral examination were obtained from both groups (the healthy \& hemodialysis patients). Each candidate had special interview to gather the information, with special case sheath described the 
usual demographical information, which matches the medical chart were recorded, from the interview our participant answered direct individual questioner regarding time \& number of brushing in the day, education level, attitude towards dental health. For hemodialysis patients, they were only asked whether any medical person explained to you the relationship between damaged structures of oral cavity and complications that occur during extraction or surgery in the maxillofacial region.

Each participant underwent an intraoral exam that was performed under head light at the bedside by using mouth mirror and probe while the patient attended the hemodialysis unit. The exclusion criteria included of edentulous patients or patients not like to cooperate. Antibiotic prophylaxis was not used, radiography was not performed.

Special descriptive case sheath for each patient, clean disposable gloves, gauze pads, examination set (mirror, probe, tweezers), periodontal probe, head light, hemodialysis unit used in the study.

Oral Health Indices: The clinical parameters used in this study in order to detect oral health were Plaque index, Periodontal Disease Index ${ }^{(26)}$. Statistical analysis was performed using SPSS software.

\section{RESULTS}

Patients were divided into three levels of education (Figure1); Pearson Chi - Square test showed significant difference ( $\mathrm{p}$-value $=0.029)$. ANOVA analysis for the education level of both groups with the gingival \& plaque indices (Tables 1,2) showed no significant results. Cross tab $\&$ correlation were done for brushing time; it showed no significant relation (Figure 2); while significant $\mathrm{p}$-value $(\mathrm{P}$-value $=0.01$ ) was shown in dentist's visits frequency (Figure 3 ). More than half of the hemodialysis patients (61.403) showed complications related to previous dental or oral treatment (Figure 4). Cross tabulation was done for complication seen in the study groups and showed significant result $(\mathrm{P}$-value $=0.008$ ) (Figure 5). Most of patients seen in the hemodialysis unit had undergone dialysis for period from 1-3 years (56.140\%). Pearson correlation for analysis of dialysis period effect \& oral health indices showed no relation of severity (Figure 6). ANOVA test also was done for gingival index and plaque index in the study groups and showed significant relation $(\mathrm{P}$-value $=0.031, \mathrm{P}$ value $=0.000)($ Tables 3,4$)$. Analysis for Decayed \& Missed teeth for healthy \& hemodialysis patients showed significant differences for the decayed teeth in the hemodialysis patients by T-test (P value 0.000) (Figures 7, 8).

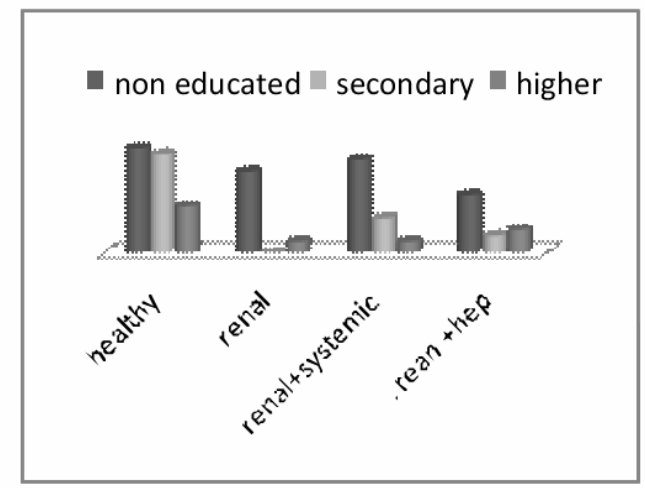

Figure 1: Education Level \& Study Groups P-value $=0.029$ (sig.) 
Table 1: ANOVA Analysis for the Education Level and Gingival Index

\begin{tabular}{|c|c|c|c|c|c|c|}
\hline & & $\begin{array}{c}\text { Sum of } \\
\text { Squares }\end{array}$ & df & $\begin{array}{c}\text { Mean } \\
\text { Square }\end{array}$ & $\mathbf{F}$ & p-value \\
\hline \multirow[t]{3}{*}{$\begin{array}{c}\text { Gingival } \\
\text { Index }\end{array}$} & $\begin{array}{c}\text { Between } \\
\text { Groups }\end{array}$ & 11.755 & 2 & 5.877 & 2.124 & .125 \\
\hline & Within & 268.355 & 97 & 2.767 & & \\
\hline & Total & 280.110 & 99 & & & \\
\hline
\end{tabular}

Table 2: ANOVA Analysis for the Education Level and Plaque Index

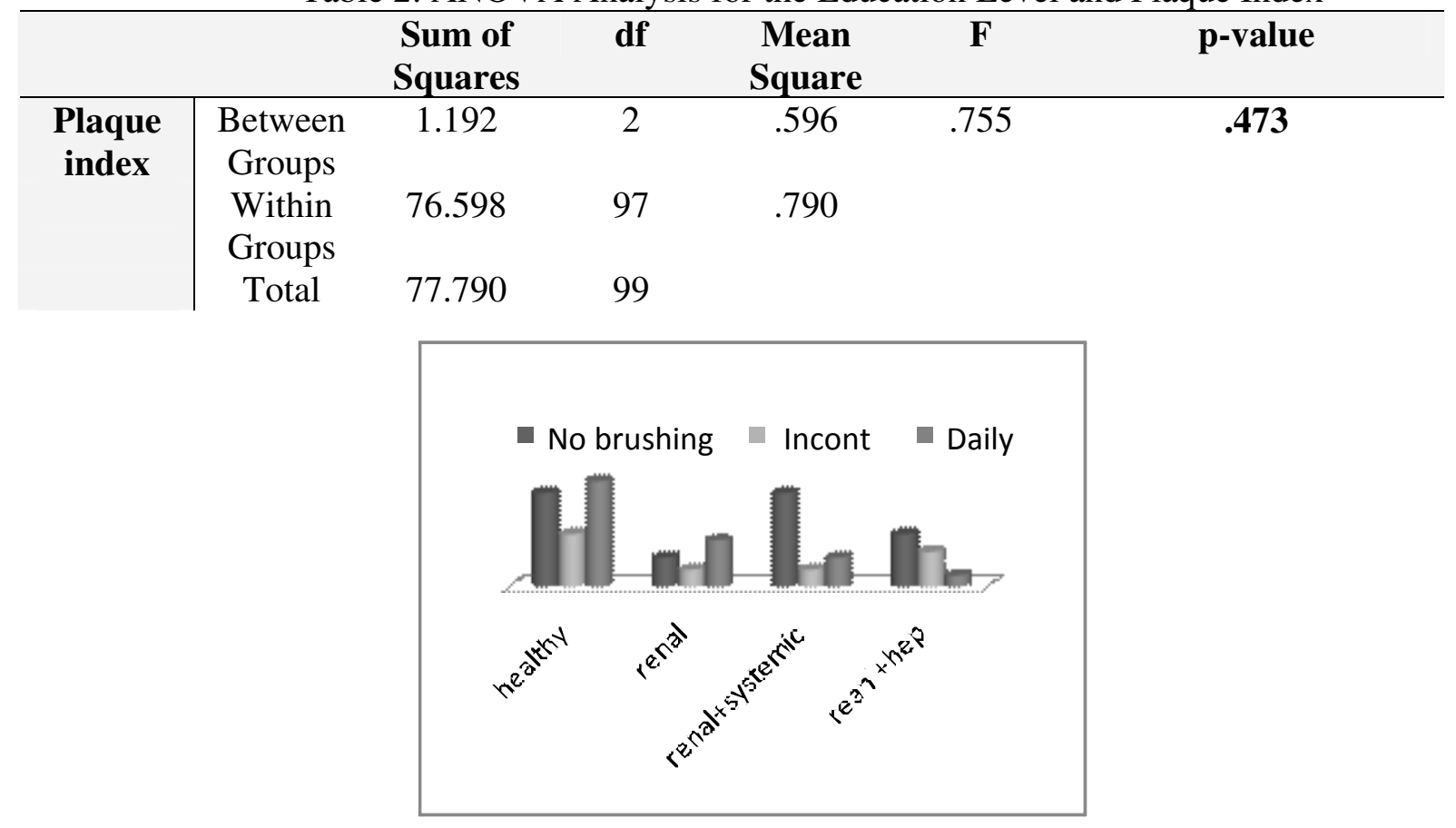

Figure 2: Brushing Frequency \& Study Groups $\mathrm{P}$ - value $=0.57$

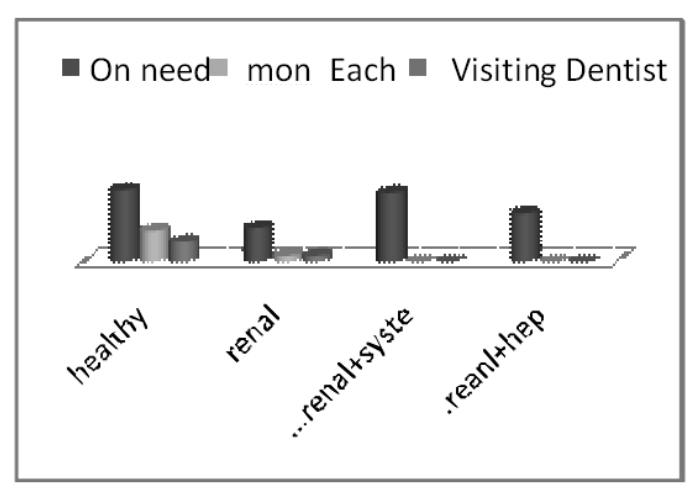

Figure 3: Visiting Dentist Frequency $\mathrm{P}$ - value $=0.01$ (sig.)

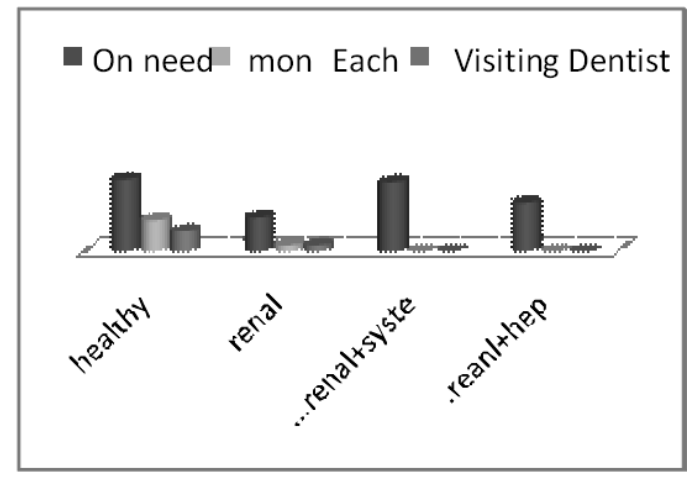

Figure 4: Explanation for Hemodialysis Patients 


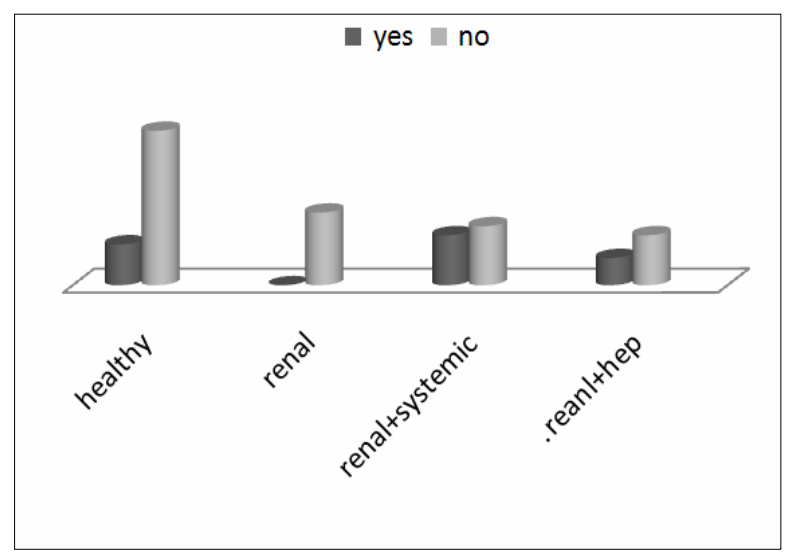

Figure 5: Complications Frequency in Disease P- value $=0.008$ (sig.)

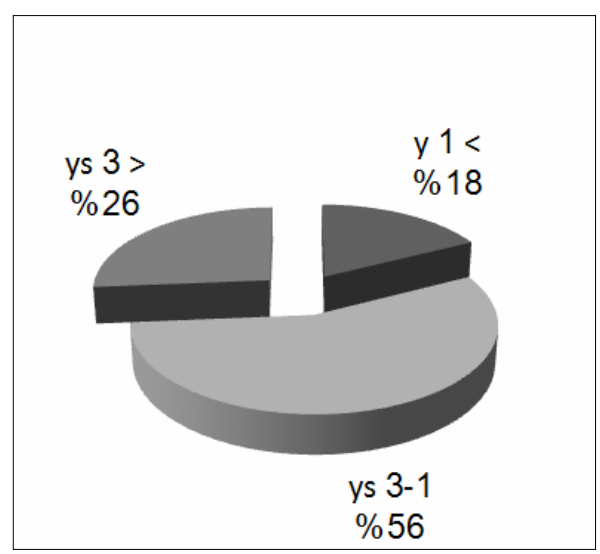

Figure 6: Duration of Dialysis

Table 3: ANOVA Test for Gingival Index

\begin{tabular}{|c|c|c|c|c|c|c|}
\hline & & $\begin{array}{c}\text { Sum of } \\
\text { Squares }\end{array}$ & df & $\begin{array}{c}\text { Mean } \\
\text { Square }\end{array}$ & $\mathbf{F}$ & $P$ value \\
\hline \multirow[t]{3}{*}{ Gingival Index } & $\begin{array}{c}\text { Between } \\
\text { Groups }\end{array}$ & 24.568 & 3 & 8.189 & 3.077 & .031 \\
\hline & Within & 255.542 & 96 & 2.662 & & \\
\hline & $\begin{array}{c}\text { Groups } \\
\text { Total }\end{array}$ & 280.110 & 99 & & & \\
\hline
\end{tabular}

Table 4: ANOVA Test for Plaque Index

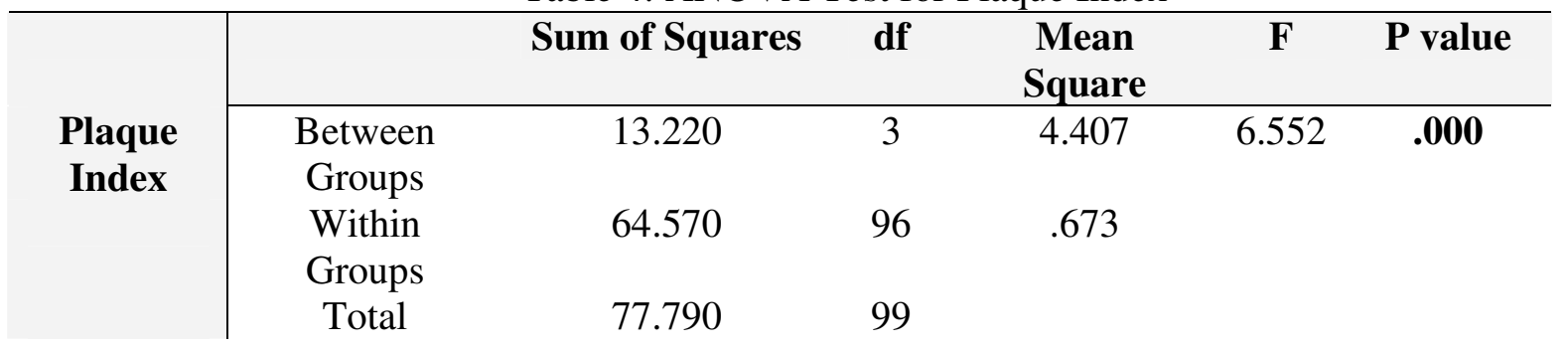




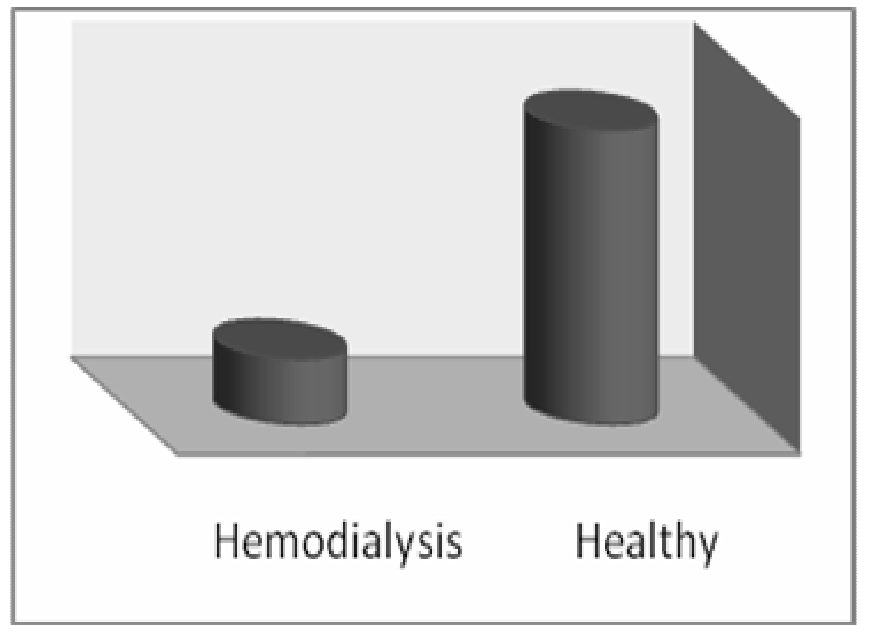

Figure 7: Mean of Decay Teeth

P- value $=0.000$ (sig.)

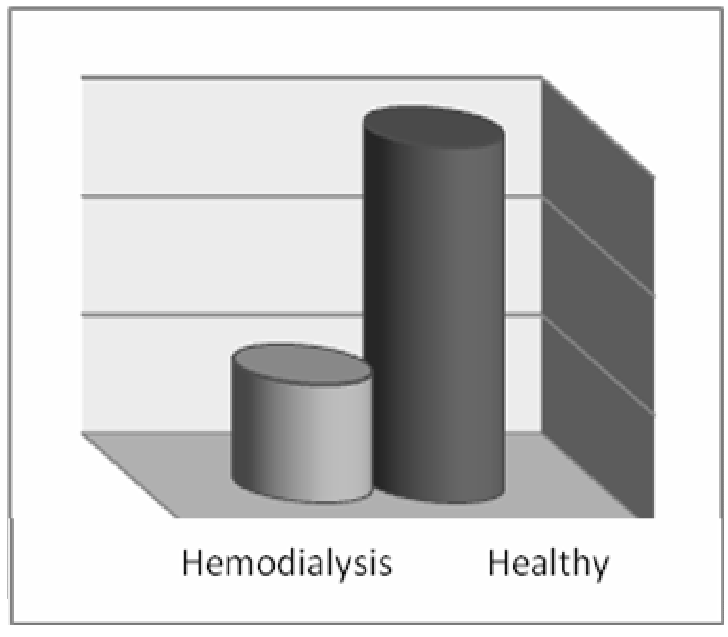

Figure 8: Mean of Loss Teeth

$\mathrm{P}$ - value $=0.986$ (non sig.)

\section{DISCUSSION}

CKD patients require special consideration, to deal with them gently \& friendly as they are suffering and psychologically up seated; this can be seen clearly from the way the questioners were answered regarding brushing frequency \& visiting dentist, which was usually done on need only for most of our patients ${ }^{(26)}$. The attitude toward dental health differed significantly between groups. Most of the hemodialysis patients were not educated for their oral health that made them more susceptible to have complications ${ }^{(27,28)}$. This can be attributed to the fact that there is lack of bilateral motivation between medical staff, dentists towards the hemodialysis patients. Most of our patients visiting dentist only on need in both groups, this also can be related to the poor attitude of our patients toward their oral health also the role of dentist explanation are missed.

Usually dialysis patients are more concerned about their medical problems as they need to undergo dialysis 2-3 times a week for 3-4 hours in each session according to their systemic condition; this might make them careless regarding their oral health ${ }^{(27)}$. Bleeding \& infection are the most oral \& maxillofacial complications that can be seen in the third group; several changes that occur in the oral cavity associated with CKD make them require special care and special considerations $(12,29,30)$. The plaque index revealed that comprehensive oral hyiegen instruction is required to improve oral self - care behavior \& prevent the initiation and progression of future dental disease \& complication. However, no intervention was implemented to educate these patients or motivate them to an acceptable oral health status ${ }^{(14)}$. Duration of dialysis showed no effect on the oral health deterioration ${ }^{(31)}$.

Significant relation concerning mild to moderate gingivitis was noticed, especially in those complaining of other systemic disease ${ }^{(32,33,34,35)}$. Although many previous authors have obtained similar results ${ }^{(36,37)}$, conflicting reports are also available that failed to detect any difference in the periodontal health in patients undergoing hemodialysis ${ }^{(18,38)}$. These results are related to their uremic state that causes immune suppression as a result of increased toxin which can affect the host response to bacterial challenges. In agreement with other authors ${ }^{(20,21)}$, we did not observe significant differences between the missed teeth of the hemodialysis patients and 
controls in the present study ${ }^{(9,18,39)}$. Recently, in a series published by Bots et al ${ }^{(18)}$, the frequency of the totally edentate state in a group of patients included in a hemodialysis program was of $23 \%$. In the present study, the prevalence of active caries was lower in the patients than in the controls. Most of hemodialysis patients showed significant difference in the decay teeth. Bots et al ${ }^{(18)}$ stated that the number of decayed teeth in the patients on dialysis was similar to that of the healthy controls.

It is concluded that:

\section{CONCLUSIONS}

- Most of the hemodialysis patients don't care for their oral health unless there is some change in the mouth or the maxillofacial region.

- Lack of bilateral motivation between doctors/or dentist and patients.

- Lack of explanation to patients that their state has relation to oral health deterioration.

- Dialysis patients are immuncompromised, as they have different medical diseases in association to renal disease itself, so they need special care and gentle manipulation in order to reduce the complications that can fatal like infection and bleeding.

- A stringent continued oral care program should be established to prevent oral disease from progressing undetected in spite of their psychological state.

- The goal of dental treatment in patients with renal disease should be the early and frequent evaluation of the oral cavity for any source of infection. Early detection of oral pathologies will permit swift correction with minimal need for extensive dental treatment.

- Regular dental visits and re-motivation in plaque control are of vital importance to ensure optimal oral health in dialysis patients in order to prevent rejection of the allograft after transplantation as a result of oral infection.

\section{REFERENCES}

1. El Kossi M. and El Nahas M. Epidemiology and Pathophysiology of Chronic Kidney Disease. Comprehensive Clinical Nephrology. $3^{\text {rd }}$ ed. New York: Mosby; 2007. p :813-814.

2. Skorecki K, Green J, and Brenner BM. Chronic renal failure. In: Kasper DL, Braunwald E, Fauci AS, Hauser SL, Longo DL and Jameson JL. Harrison's Principles of Internal Medicine. New York: McGraw-Hill; 2005. P: 1653-63.

3. Farrington K, Greenwood R, Ahmad S. Hemodialysis: mechanisms, outcome, and Adequacy. Comprehensive Clinical Nephrology. 2nd Ed. New York: Mosby; 2003. P: 975-990.

4. Proctor R, Kumar N, Stein A, Moles D, Porter S. Oral and dental aspects of chronic renal failure. J Dent Res 2005; 84 (3):199-208.

5. Berkow R., Bondy D. C. and Bondy P. K. Chronic renal insufficiency, in The Merck Manual of Diagnosis and Therapy. USA. 1982; P: 1110 - 1207.

6. Guzeldemir E.; Toygar H., Tasdelen B. and Torun D. Oral health-related quality of life and periodontal health status in patients undergoing hemodialysis. JADA. 2009; (140).

7. Winearls C.; Clinical evaluation and manifestation of chronic renal failure. Comprehensive Clinical Nephrology. 2nd Ed. New York: Mosby; 2003:857-872.

8. Epstein SR, Mandel I, Scopp IW. Salivary composition and calculus formation in patients undergoing hemodialysis. J Periodontol 1980; 51(6):336-338.

9. Gavaldá C, Bágan J, Scully C, Silvestre F, Milián M, and Jiménez Y. Renal hemodialysis patients: oral, salivary, dental and periodontal findings in 105 adult cases. Oral Disease 1999; 5 (4):299-302.

10. De Rossi S. S. and Glick M. Dental considerations for the patient with renal disease receiving hemodialysis. Journal of the American Dental Association, 1996; 127(2): 211-219. 
11. Sowell S. B. Dental care for patients with renal failure and renal transplants. The Journal of the American Dental Association. 1982; 104 (2):171-177.

12. Epstein S. R., Mandel I. and Scopp I. W. Salivary composition and calculus formation in patients undergoing hemodialysis. Journal of Periodontology. 1980; 51(6): 336-338.

13. Al-Wahadni A. and Al-Omari M. A. Dental diseases in a Jordanian population on renal dialysis. Quintessence International. 2003; 34 (5): 343-347.

14. Peterson S., Woodhead J. and Crall J. Caries resistance in children with chronic renal failure: plaque $\mathrm{pH}$, salivary pH, and salivary composition. Pediatric Research. 1985; 19 (8): 796-799.

15. Levy H. M. Dental considerations for the patient receiving dialysis for renal failure. Special Care in Dentistry. 1988; 8 (1): 34-36.

16. Bots C. P. Poorterman J. H. G., H. S. Brand, et al., "The oral health status of dentate patients with chronic renal failure undergoing dialysis therapy," Oral Diseases, vol. 12, no. 2, pp. 176-180, 2006.

17. Schuller A. A. and Holst D. Oral status indicators DMFT and FS-T: reflections on index selection. European Journal of Oral Sciences. 2001; 109 (3): 155-159.

18. Bayraktar G., Kazancioglu R., Bozfakioglu S., Yildiz A. and Ark E. Evaluation of salivary parameters and dental status in adult hemodialysis patients. Clinical Nephrology. 2004; 62 (5): 380-383.

19. AlNowaiser A., Roberts G. J., Trompeter R. S., Wilson M. and V. S. Lucas. Oral health in children with chronic renal failure. Pediatric Nephrology. 2003; 18 (1): 39-45.

20. Kitsou V. K., Konstantinidis A. and Siamopoulos K. C. Chronic renal failure and periodontal disease. Renal Failure. 2000; 22 (3): 307-318.

21. Clark D. B. Dental findings in patients with chronic renal failure. An overview. Journal of the Canadian Dental Association. 1987; 53 (10): 781-785.

22. Scannapieco F. A., Bush R. B. and Paju S. Associations between periodontal disease and risk for atherosclerosis, cardiovascular disease, and stroke. A systematic review. Annals of Periodontology. 2003; 8 (1): $38-53$.

23. Scannapieco F. A., Bush R. B. and Paju S. Associations between periodontal disease and risk for nosocomial bacterial pneumonia and chronic obstructive pulmonary disease. A systematic review. Annals of Periodontology. 2003; 8 (1): 54-69.

24. Rhonda J.M and Raylene R.M. Patient assessment in pharmacy practice, Clinical Nephrology 2003; $307-314$.

25. Thomas D., Joseph J., Francis B. and Mohanta. Effect of patient counseling on quality of life of hemodialysis patients in India. Biotechnol. \& Biotechnol Eq: 2009; 1127-1129??

26. Westbrook SD. Dental management of patients receiving hemodialysis and kidney transplant. JADA. 1978; 96(30):464-468.

27. Bayraktar G., Kurtulus I., Kazancioglu R. and Bayramgurler I. Effect of Educational Level on Oral Health in Peritoneal and Hemodialysis Patients. International Journal of Dentistry. 2005;245-247

28. Dencheva M., Dialysis, Renal transplantion and Oral health. Biotechnol. \& Biotechnol Eq. 2010; 24 (2): 18781881.

29. Gabriel R. Morbidity and mortality of long-term haemodialysis: a review. J R Soc Med. 1984; 77: 595-601.

30. Remuzzi G and Pusineri F. Coagulation defects in uremia. Kidney Int. 1988; 33: 513-517

31. Kaplan De-Nour A and Czackes W. The influence of patient s personality on adjustment ton chronic dialysis. J Nerv Ment Dis 1976; 162: 323-333.

32. Oshrain HI, Mendre S and Mandel ID. Periodontal status of patients with reduced immunocapacity. J periodontal 1979; 50: 185-188

33. Naugle-Kdarby-ML, Bauman-DB, and Lineberger-TL. The oral health status of individuals on renal dialysis. Ann-Periodontal. 1998; 3(1): 197-205.

34. Brown LJ, Oliver RC and Lee H. Periodontal diseases in the U.S. in 1981: Prevalence, severity, extent, and role in tooth mobility. J Periodontal 1989; 60: 363-370.

35. Bottomley WK, Cloffi RF and Martin A. Dental management of the patient treated with renal transplantation: preoperative and post operative considerations. JADA. 1972; 85 (12): 1330-1335.

36. Rahmati MA, Craig RG, Homel P, Kaysen GA, and Levin NW. Serum markers of periodontal disease status and inflammation in hemodialysis patients. Am J Kidney Dis. 2002; 40:983-9. 
37. Borawski J, Wilczyńska-Borawska M, Stokowska W, and Myśliwiec M. The periodontal status of pre-dialysis chronic kidney disease and maintenance dialysis patients. Nephrol Dial Transplant. 2007; 22:457-64.

38. Nunn JH, Sharp J, Lambert HJ, Plant ND and Coulhtard MG. Oral health in children with renal disease. Pediatr Nephrol. 2000; 14:997-1001.

39. Locsey L, Alberth M, Mauks G. Dental management of chronic hemodialysis patients. Int Urol Nephrol 1986; 18:211-3. 